\title{
Pengaruh Penggunaan Model Pembelajaran Mastery LEARNING (BELAJAR TUNTAS) TERHADAP KEMAMPUAN PEMECAHAN MASALAH MATEMATIKA SiSWA KELAS X SMA 'AISYIYAH 1 PALEMBANG
}

\author{
THE EFFECT OF THE USE MASTERY LEARNing MODEL (BELAJAR TUNTAS) THROUGH \\ Mathematical Problem Solving Skill Students of X Grade Math High \\ SCHOOL 'AisYiYaH 1 PalEMBang
}

\author{
Eliza Ayu Pratiwi' ${ }^{1}$ Amir Rusdi ${ }^{2}$ dan Agustiany Dumeva Putri ${ }^{3}$ \\ 1,2,3 Pendidikan Matematika, Universitas Islam Negeri Raden Fatah Palembang \\ 1 elizaayup@yahoo.com
}

\begin{abstract}
Abstrak
Penelitian ini bertujuan untuk mengetahui pengaruh penggunaan model pembelajaran mastery learning (belajar tuntas) terhadap kemampuan pemecahan masalah matematika siswa dikelas $\mathrm{X}$ SMA 'Aisyiyah 1 Palembang. Jenis penelitian yang digunakan adalah true exprimental design dengan desain pretest - posttest control group design, populasi yang digunakan adalah seluruh siswa kelas X yang ada di SMA 'Aisyiyah 1 Palembang tahun ajaran 2015/2016. Penelitian ini mengambil dua kelas sebagai sampel yang diambil dengan menggunakan teknik cluster random sampling yaitu kelas X4 dengan jumlah 37 siswa sebagai kontrol dan kelas X1 berjumlah 37 siswa sebagai kelas ekprimen. Pengumpulan data dilakukan dengan menggunakan instrumen berupa tes kemampuan pemecahan masalah matematika dan observasi kepada siswa. Data yang diperoleh dari hasil tes digunakan untuk menguji hipotesis penelitian dengan menggunakan uji-t. Dari hasil analisis diperoleh bahwa terdapat pengaruh positif penggunaan model pembelajaran mastery learning (belajar tuntas) terhadap kemampuan pemecahan masalah matematika siswa dan hasil rata-rata observasi aktivitas kemampuan pemecahan masalah matematika siswa sebesar 74.

Kata Kunci: model pembelajaran mastery learning (belajar tuntas), kemampuan pemecahan masalah matematika siswa, sistem persamaan linear.
\end{abstract}

\begin{abstract}
This research aims to determine the effect of using the mastery learning models to the mathematical problem solving ability of first grader of 'Aisyiyah 1's Senior High School Palembang. The type of this research is the true experimental design with the design pretest posttest control group design, the populations are all first grader of 'Aisyiyah 1's Senior High School Palembang 2015/2016. This research took two classes as a samples by using the cluster random sampling technique. The classes are X4 with 37 students as a control and X1 with 37 students as a experiment class. The research was conducted of eight meetings. The collection of datas are done by using an instrument which are mathematical problem solving ability test and observation to students. The datas obtained from the test are used to test the research hypothesis by using $t_{\text {-test }}$. From the analysis, this shows that there is positive effect of using the mastery learning to the mathematical problem solving abilities of students and the average result of observation the ability mathematical problem solving is 74 .

Keyword: the mastery learning model learning, mathematical problem-solving ability of students, the system of linear equations.
\end{abstract}




\section{Pendahuluan}

Perkembangan dan kemajuan teknologi semakin berkembang pesat serta persaingan bebas telah mengantarkan manusia pada era globalisasi, untuk itu persiapan sumber daya manusia yang unggul dan tangguh mutlak dilakukan sebagai bekal untuk menghadapi berbagai tantangan yang semakin kompleks dimasa yang akan datang. Melalui proses pendidikan manusia dapat mengembangkan berbagai kemampuan yang ada di dalam dirinya baik dari segi intelektual, mental, dan spiritual. Kualitas sumber daya manusia pada hakikatnya ditentukan oleh kualitas pendidikan yang telah ditempuhnya. Semakin baik kualitas pendidikan yang diterapkan maka akan semakin baik pula sumber daya manusia yang dihasilkan.

Pendidikan merupakan suatu hal yang dinamis, oleh karena itu pembaharuan pendidikan sudah selayaknya untuk selalu dilakukan secara sinergis dan berkesinambungan demi terwujudnya sumber daya manusia yang unggul dan tangguh sesuai dengan tuntutan zaman. Dengan sumber daya manusia yang unggul dan tangguh diharapkan dapat meningkatkan harkat dan martabat bangsa kita serta dapat bersaing dengan seluruh dunia.

Banyak kendala yang dihadapi dalam sistem pendidikan sekolah, salah satu diantara masalah besar dalam bidang pendidikan di Indonesia yang banyak dibicarakan adalah rendahnya mutu pendidikan yang tercermin dari rendahnya prestasi belajar dan penyimpangan perilaku (akhlak). Masalah lain dalam bidang pendidikan di Indonesia yang juga banyak dibicarakan adalah bahwa pendekatan dalam pembelajaran masih terlalu didominasi peran guru (teacher certed), walaupun sudah sering kali diberi pelatihan (Majid, 2013: 151). Oleh karena itu, kita harus meningkatkan mutu pendidikan di Indonesia. Para guru harus memiliki keterampilan memilih dan menggunakan metode mengajar yang tepat untuk diterapkan dalam sistem pembelajaran dapat berjalan dengan lancar dan efektif.

Salah satu yang perlu ditingkatkan adalah pembelajaran matematika. Dalam dunia pendidikan, matematika salah satu bidang studi yang mempunyai peranan sangat penting. Hal itu dapat dilihat bahwa metematika diajarkan pada semua jenjang pendidikan.

Berdasarkan pengamatan peneliti dibulan September sampai November pada saat pelaksanaan PPLK II dan wawancara dengan guru, diperoleh beberapa informasi mengenai pengajaran matematika di SMA 'Aisyiyah 1 Palembang. Selama ini dalam kegiatan pembelajaran siswa kurang menguasai dengan tuntas materi yang diajarkan oleh gurunya. Hal ini dapat dilihat dari nilai siswa, yang mana masih ada sebagian siswa yang belum mencapai nilai di atas KKM. Akibatnya, siswa akan mengalami kesulitan untuk menerima materi-materi selanjutnya. 
Selain itu, tingkat kemampuan pemecahan masalah siswa masih rendah. Hal ini menunjukan bahwa siswa mengalami kesulitan dalam menyelesaikan soal pemecahan masalah. Pada umumnya, dalam mengerjakan soal pemecahan masalah siswa terfokus pada jawaban akhir dan cenderung mengesampingkan cara pemecahan. Selain itu, kemampuan siswa dalam memahami masalah masih rendah sehingga dalam penyelesaian soal terasa sulit bagi siswa. Ini menandakan bahwa kemampuan pemecahan masalah siswa masih rendah.

Proses pendidikan di sekolah saat ini belum menerapkan pembelajaran secara tuntas. Akibatnya, tidak aneh bila banyak siswa yang tidak menguasai materi pembelajaran meskipun sudah dinyatakan lulus dari sekolah (Majid, 2013: 151). Sistem persekolahan yang tidak memberikan pembelajaran secara tuntas ini dapat menyebabkan sebagian orang berpendapat bahwa banyak pemborosan baik dari segi waktu maupun materil. Permasalahan yang ada dilapangan ialah siswa mengalami kesulitan dalam memahami tahapan-tahapan yang ada dalam menyelesaikan soal-soal matematika, terlebih jika siswa yang bersangkutan belum memahami materimateri yang diajarkan sebelumnya.

Penggunaan model pembelajaran khususnya dalam mata pelajaran matematika sangat diperlukan agar dapat meningkatkan semangat belajar siswa, mengembangkan kreativitas siswa, dan menjalin interaksi yang baik antar siswa dengan siswa maupun siswa dengan gurunya. Penggunaan model pembelajaran juga dapat meningkatkan pemahaman, keterampilan dan sikap tertentu peserta didik. Model pembelajaran adalah bentuk atau tipe kegiatan pembelajaran yang digunakan untuk menyampaikan bahan ajar oleh guru kepada siswa (Sukardi, 2013: 29).

Salah satu model pembelajaran yang diduga dapat meningkatkan kemampuan pemecahan masalah adalah penerapan model pembelajaran belajar tuntas (Mastery Learning).

Menurut Joice and Weil (1995) (dalam Wena, 2014: 184) mengatakan bahwa, model pembelajaran belajar tuntas (Mastery Learning) dikembangkan oleh John B. Caroll (1971) dan Benjamin Bloom (1971). Belajar tuntas menyajikan suatu cara yang menarik dan ringkas meningkatkan unjuk kerja siswa ketingkat pencapaian suatu pokok bahasan yang lebih memuaskan. Guru dalam mastery learning, harus berupaya mengantarkan kegiatan anak didik ke arah tercapainya peguasaan penuh terhadap bahan yang diberikan. Dalam mastery learning guru membagi materi pembelajaran menjadi unit-unit yang lebih kecil dengan harapan masing-masing siswa dapat memahami materi pembelajaran secara tuntas.

Bertitik tolak dari permasalahan diatas maka peneliti tertarik untuk meneliti penggunaan model pembelajaran mastery learning (belajar tuntas) pada pembelajaran matematika di SMA 'Aisyiyah 1 Palembang. Untuk itu peneliti 
berencana melakukan penelitian dengan judul "Pengaruh Penggunaan Model Pembelajaran Mastery Learning (Belajar Tuntas) Terhadap Kemampuan Pemecahan Masalah Matematika Siswa Kelas X SMA 'Aisyiyah 1 Palembang”.

Berdasarkan uraian di atas maka yang menjadi permasalahan dalam penelitian ini adalah "Apakah terdapat pengaruh penggunaan model pembelajaran mastery learning (belajar tuntas) terhadap kemampuan pemecahan masalah matematika siswa kelas X SMA 'Aisyiyah 1 Palembang?"

Berdasarkan rumusan masalah diatas penelitian ini dilakukan dengan tujuan untuk mengetahui pengaruh penggunaan model pembelajaran mastery learning (belajar tuntas) terhadap kemampuan pemecahan masalah matematika siswa kelas X SMA ‘Aisyiyah 1 Palembang.

\section{Metode}

Penelitian ini digolongkan kedalam penelitian True-Experimental Design, karena pada desain ini peneliti dapat mengontrol semua variabel luar yang mempengaruhi jalannya eksperimen. Ciri utama dari true-experimental design adalah bahwa, sampel yang digunakan untuk eksperimen maupun sebagai kelompok kontrol diambil secara random dari populasi tertentu. Jadi cirinya adalah adanya kelompok kontrol dan sampel dipilih secara random (Sugiyono, 2013: 109). Pada dasarnya jenis penelitian ini bertujuan untuk mengetahui pengaruh suatu model pembelajaran sebelum dan sesudah diberi perlakuan. Penelitian ini bertujuan untuk mengetahui pengaruh penggunaan model pembelajaran mastery learning (belajar tuntas) terhadap kemampuan pemecahan masalah matematika siswa kelas X SMA 'Aisyiyah 1 Palembang.

Dalam penelitian ini yang akan digunakan adalah Pretest-Posttest Control Group Design dimana terdapat dua kelompok yang dipilih secara random, kemudian diberi pretest untuk mengetahui keadaan awal adakah perbedaan antara kelompok eksperimen dan kelompok kontrol.

Adapun pola dari Pretest - Posttest Control Group Design ditunjukkan sebagai berikut:

Tabel 1.

Desain Penelitian Pretest - Posttest Control Group Design

\begin{tabular}{cccc}
\hline$E$ & $\mathrm{O}_{1}$ & $X$ & $\mathrm{O}_{2}$ \\
\hline $\mathrm{K}$ & $\mathrm{O}_{3}$ & & $\mathrm{O}_{4}$
\end{tabular}

Keterangan:

E : Kelompok Eksprimen yaitu kelas yang menggunakan model pembelajaran mastery learning (belajar tuntas).

$\mathrm{K}$ : Kelas Kontrol yaitu kelas yang menggunakan model pembelajaran konvensional.

$X$ : Treatment ( kelompok atas sebagai kelompok eksprimen diberi treatment yaitu Model Pembelajaran Mastery Learning (belajar tuntas) sedangkan kelompok bawah yang merupakan kelompok kontrol, yaitu menggunakan model 
pembelajaran konvensional dengan metode ceramah dan tanya jawab).

$\mathrm{O}_{1}$ dan $\mathrm{O}_{3}$ : Tes awal untuk melihat kemampuan awal siswa sebelum treatment dilakukan.

$\mathrm{O}_{2}$ dan $\mathrm{O}_{4}$ : Tes akhir untuk melihat kemampuan akhir siswa setelah treatment dilakukan.

(Sugiyono, 2013:112)

Variabel dalam penelitian ini terdiri dari variabel bebas dan variabel terikat. Adapun yang menjadi variabel bebas dalam penelitian ini adalah penggunaan model pembelajaran mastery learning (belajar tuntas) dan variabel terikat di dalam penelitian ini adalah adalah kemampuan pemecahan masalah matematika siswa kelas X SMA Aisyiyah 1 Palembang.

Populasi dalam penelitian ini adalah seluruh siswa kelas $X$ di SMA Aisyiyah 1 Palembang tahun ajaran 2015/2016 yang berjumlah 147 orang yang terdiri dari 4 kelas. Untuk teknik pengambilan sampel pada penelitian ini menggunakan teknik cluster random sampling.

Dalam pengumpulan data tersebut peneliti menggunakan data observasi dan data tes. Observasi dilakukan dengan mengamati dan mencatat kegiatan pembelajaran dikelas. Observasi keterlaksanaan pembelajaran dan aktifitas pemecahan masalah matematika siswa dilakukan dengan menggunakan lembar observasi yang telah dipersiapkan. Data yang diperoleh berupa hasil observasi keterlaksanaan pembelajaran dan hasil observasi aktifitas pemecahan masalah matematika siswa.

Tes diberikan kepada siswa pada awal (pretest) dan akhir (posttest) siklus pembelajaran untuk mengetahui kemampuan pemecahan masalah matematika siswa tersebut. Sebelum soal diberikan pada sampel penelitian soal tersebut akan akan diuji coba terlebih dahulu untuk menunjukan tingkat kevalidan, realibilitas dan tingkat kesukaran yang sesuai dengan kriteria yang diinginkan.

\section{A. Uji Validitas Tes}

Dalam menentukan validitas isi digunakan rumus Product Moment yaitu:

$r_{X Y}$

$=\frac{N \sum X Y-\left(\sum X\right)\left(\sum Y\right)}{\sqrt{\left\{N \sum X^{2}-\left(\sum X\right)^{2}\right\}\left\{N \sum Y^{2}-\left(\sum Y\right)^{2}\right\}}}$ (Sudijono, A, 2013: 181)

Kemudian hasil $r_{x y}$ dibandingkan dengan harga $r$ Product Moment dengan taraf signifikan 5\%. Jika $r_{x y}>r_{\text {tabel }}$ dengan $\alpha=5 \%$ maka item soal dikatakan valid atau dengan kata lain jika harga $r$ lebih $r_{x y}<$ $r_{\text {tabel }}$ maka item soal tidak valid.

\section{B. Uji Validitas Pakar}

Dalam penelitian ini peneliti akan menguji instrumen RPP, LKS, soal pretest, soal postest, dan lembar observasi menggunakan angket dengan skala sikap atau numeric rating scale.

Tabel 2.

\begin{tabular}{cc}
\multicolumn{2}{c}{ Kriteria Penskoran Validitas Pakar } \\
\hline Skor & Keterangan \\
\hline 1 & Sangat tidak valid \\
\hline 2 & Tidak valid \\
\hline
\end{tabular}




\begin{tabular}{|lc|}
\hline 3 & Valid \\
\hline 4 & Sangat valid \\
\hline
\end{tabular}

Kemudian peneliti menghitung ratarata skor setiap validator. Kriteria kevalidan instrumen RPP, LKS, soal pretest, soal postest, dan lembar observasi dapat dilihat dari tabel berikut:

Tabel 3.

Kriteria Kevalidan

\begin{tabular}{ccc|}
\hline Skor & Interval & Kriteria \\
\hline 1 & $0,1<R r<1,0$ & $\begin{array}{c}\text { Sangat tidak } \\
\text { valid }\end{array}$ \\
\hline 2 & $1,1<R r<2,0$ & Tidak valid \\
\hline 3 & $2,1<R r<3,0$ & Valid \\
\hline 4 & $3,1<R r<4,1$ & Sangat valid \\
\hline
\end{tabular}

\section{Uji Reliabilitas}

Untuk mengetahui reabilitas tes dengan soal uraian dapat menggunakan rumus Alpha sebagai berikut:

$$
r_{11}=\left(\frac{n}{n-1}\right)\left(1-\frac{\sum \sigma_{i}^{2}}{\sigma_{t}^{2}}\right)
$$

dengan rumus varian total

$\sigma_{i}^{2}=\frac{\sum x_{i}{ }^{2}-\frac{\left(\sum x_{i}\right)^{2}}{n}}{n}$ dan $\sigma_{t}^{2}=\frac{\sum y^{2}-\frac{\left(\sum y\right)^{2}}{n}}{n}$

\section{Hasil dan Pembahasan}

\section{A. Hasil Penelitian}

Sebelum melakukan penelitian, peneliti terlebih dahulu melakukan validasi terhadap instrumen penelitian yang akan digunakan baik RPP, LKS, soal pretest, soal posttest, dan lembar observasi. Adapun nilai rata-rata total validasi yang diberikan oleh para validator untuk masing-masing instrumen dapat dilihat pada tabel di bawah ini:

Tabel 4.

Nilai Rata-rata Total Validator

\begin{tabular}{|clcl|}
\hline No & $\begin{array}{l}\text { Instrumen } \\
\text { Penelitian }\end{array}$ & $\begin{array}{c}\text { Nilai Rata- } \\
\text { Rata Validator }\end{array}$ & Keterangan \\
\hline 1. & RPP & 3,3 & Sangat Valid \\
\hline 2. & LKS & 3,32 & Sangat Valid \\
\hline 3. & Soal Pretest & 3,2 & Sangat Valid \\
\hline 4. & $\begin{array}{l}\text { Soal } \\
\text { Posttest }\end{array}$ & 3,2 & Sangat Valid \\
\hline 5. & $\begin{array}{l}\text { Lembar } \\
\text { Observasi }\end{array}$ & 3,06 & Valid \\
\hline
\end{tabular}

Untuk validitas soal tes rumus korelasi yang dipergunakan adalah korelasi product moment. Hasil uji coba soal pretest dapat dilihat pada tabel berikut:

Tabel 5.

Hasil Validasi Soal Pretest

\begin{tabular}{|cccc|}
\hline \multirow{2}{*}{ Item/Soal } & \multicolumn{3}{c}{ Validitas } \\
\cline { 2 - 4 } & $\boldsymbol{r}_{\text {hitung }}$ & $\boldsymbol{r}_{\text {tabel }}$ & Kriteria \\
\hline 1 & 0,517 & 0,441 & Valid \\
\hline 2 & 0,484 & 0,441 & Valid \\
\hline 3 & 0,705 & 0,441 & Valid \\
\hline 4 & 0,867 & 0,441 & Valid \\
\hline 5 & 0,881 & 0,441 & Valid \\
\hline 6 & 0,420 & 0,441 & Tidak Valid \\
\hline 7 & 0,702 & 0,441 & Valid \\
\hline
\end{tabular}

Dari hasil uji coba ini dapat disimpulkan bahwa soal tes awal (pretest) pada materi sistem persamaan linear dua variabel dan tiga variabel pada penelitian ini adalah berkriteria valid kecuali pada Item/Soal 6 .

Untuk uji reliabilitas rumus yang digunakan adalah rumus Alpha. Dari perhitungan didapat $r_{11}=0,771$ dan $r_{\text {tabel }}$ $=0,441$ maka $r_{11}>r_{\text {tabel }}$. Ini berarti instrumen tes tersebut reliabel.

Hasil ujicoba soal posttest dapat dilihat pada tabel berikut:

Tabel 6.

Hasil Validasi Soal Posttest

\begin{tabular}{cccc|}
\hline \multirow{2}{*}{ Item/Soal } & \multicolumn{3}{c}{ Validitas } \\
\cline { 2 - 4 } & $\boldsymbol{r}_{\text {hitung }}$ & $\boldsymbol{r}_{\text {tabel }}$ & Kriteria \\
\hline 1 & 0,749 & 0,441 & Valid \\
\hline 2 & 0,725 & 0,441 & Valid
\end{tabular}




\begin{tabular}{|cccc|}
\hline 3 & 0,814 & 0,441 & Valid \\
\hline 4 & 0,874 & 0,441 & Valid \\
\hline 5 & 0,857 & 0,441 & Valid \\
\hline 6 & 0,401 & 0,441 & Tidak Valid \\
\hline 7 & 0,699 & 0,441 & Valid \\
\hline
\end{tabular}

Dari hasil uji coba ini dapat disimpulkan bahwa soal tes akhir (posttest) pada materi sistem persamaan linear dua variabel dan tiga variabel pada penelitian ini adalah berkriteria valid kecuali pada Item/Soal 6 .

Dari perhitungan uji reliabilitas didapat $r_{11}=0,838$ dan $r_{\text {tabel }}=0,441$ maka $r_{11}>$ $r_{\text {tabel. }}$ Ini berarti instrumen tes tersebut reliabel.

Setelah soal tes divalidasikan peneliti memberikan pretest kepada siswa untuk dikerjakan oleh siswa sebelum proses pembelajaran berlangsung sebagai tes awal. Hasil yang mereka peroleh selama melaksanakan pretes tersebut dapat di lihat pada grafik di bawah ini:

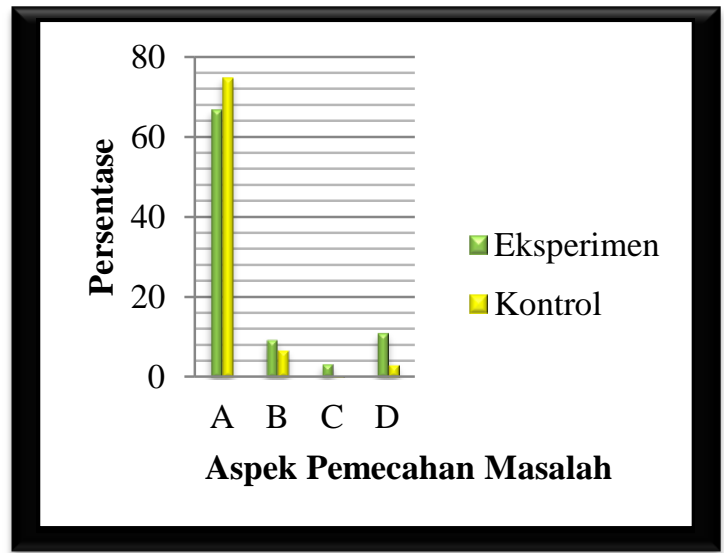

Gambar 1. Rata-Rata Skor Kemampuan Pemecahan Masalah Matematika pada Pretest Kelas Eksperimen dan Kelas Kontrol.

Keterangan aspek:

A : Kemampuan memahami masalah
B : Kemampuan merencanakan penyelesaian

C : Kemampuan menyelesaikan masalah

D : Kemampuan memeriksa kembali

Berdasarkan diagram diatas skor kemampuan pemecahan masalah matematika siswa yang rendah terdapat pada indikator ke 3 yaitu kemampuan menyelesaikan masalah. Dalam hal ini, siswa hanya memberikan penjelasan apa yang diketahui/ditanya pada soal tersebut tanpa menjelaskan lebih rinci permasalahan soal selain itu, siswa juga mengesampingkan langkah-langkah dalam penyelesaian masalah.

Setelah selesai melaksanakan proses pembelajaran dengan model pembelajaran mastery learning (belajar tuntas) pada kelas eksperimen dan model pembelajaran konvensional pada kelas kontrol maka siswa di beri tes akhir (posttest). Hasil yang mereka dapat setiap aspek dapat di lihat pada grafik dibawah ini:

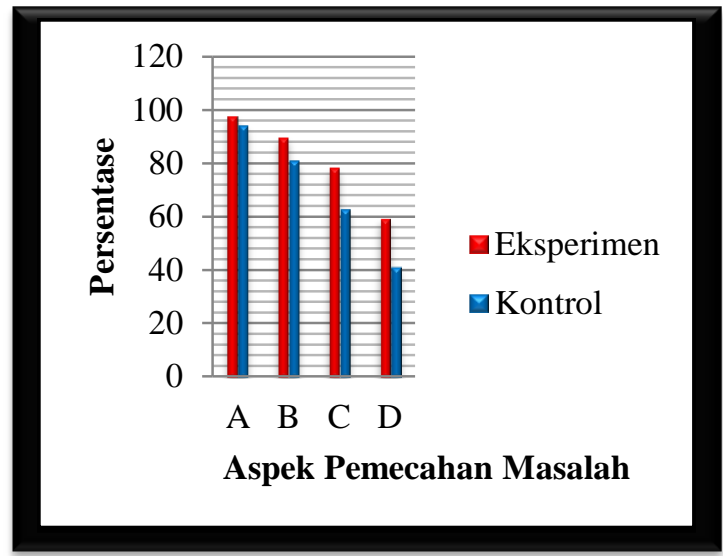

Gambar 2. Rata-Rata Skor Kemampuan Pemecahan Masalah Matematika pada Posttest Kelas Eksperimen dan Kelas Kontrol. 
Berdasarkan grafik diatas, tampak bahwa dari setiap aspek pemecahan masalah pada kelas eksperimen sedikit lebih besar dari pada kelas kontrol. Ini menunjukkan bahwa terdapat pengaruh model pembelajanan mastery learning (belajar tuntas) terhadap kemampuan pemecahan masalah matematika siswa. Selain itu, materi juga mempengaruhi hasil tes kemampuan pemecahan masalah matematika siswa. Semakin tinggi kesulitan siswa dalam memahami materi pada setiap pertemuannya maka akan semakin sulit juga siswa dalam menyelesaikan permasahan soal.

\section{B. Analisis Data}

1) Hasil Observasi Aktivitas Kemampuan Pemecahan Masalah Matematika Siswa

Berikut hasil analisis pengamatan yang diperoleh dari 6 kali pertemuan dengan menggunakan panduan instrumen lembar observasi:

Tabel 7.

Hasil Observasi Aktivitas Kemampuan Pemecahan Masalah Matematika Siswa Selama 6 Pertemuan

\begin{tabular}{|c|c|c|c|}
\hline Skor & Kategori & Frekuensi & Persentase \\
\hline $86-100$ & $\begin{array}{c}\text { Sangat } \\
\text { Baik }\end{array}$ & 1 & 2,7 \\
\hline $71-85$ & Baik & 25 & 67,6 \\
\hline $56-70$ & Cukup & 10 & 27 \\
\hline $41-55$ & Kurang & 1 & 2,7 \\
\hline $26-40$ & $\begin{array}{l}\text { Sangat } \\
\text { Kurang }\end{array}$ & 0 & 0 \\
\hline \multicolumn{2}{|c|}{ Jumlah } & 37 & 100 \\
\hline
\end{tabular}

Pada lembar observasi aktivitas kemampuan pemecahan masalah matematika siswa terdapat 4 indikator yaitu memahami masalah, merencanakan masalah, melaksanakan penyelesaian, dan memeriksa kembali.

2) Analisis Data Tes

Adapun hasil pretest untuk kelas eksperimen dan kelas kontrol dapat dilihat pada tabel dibawah ini:

Tabel 8.

Nilai Tes Awal (Pretest)

\begin{tabular}{cccc|}
\hline Kelompok & $\begin{array}{c}\text { Nilai } \\
\text { tertinggi }\end{array}$ & $\begin{array}{c}\text { Nilai } \\
\text { rendah }\end{array}$ & Mean \\
\hline Eksperimen & 31 & 8 & 22,26 \\
\hline Kontrol & 29 & 6 & 20,80 \\
\hline
\end{tabular}

Uji normalitas data dilakukan dengan uji kemiringan kurva. Data dikatakan berdistribusi normal apabila harga kemiringan $-1<K m<1$. Hasil uji normalitas untuk masing - masing kelompok dan uji homogenitas pada tes awal dilihat dalam tabel berikut ini:

Tabel 9.

Hasil Uji Normalitas Tes Awal (Pretest)

\begin{tabular}{ccccc}
\hline Kelas & $\begin{array}{c}\text { Varian } \\
\mathbf{s}\end{array}$ & $\mathrm{Km}$ & Rentang & $\begin{array}{c}\text { Uji } \\
\text { Normalitas }\end{array}$ \\
\hline Eksperimen & 48,74 & $-0,58$ & & $\begin{array}{c}\text { Distribusi } \\
\text { Normal }\end{array}$ \\
\cline { 2 - 3 } & 29,38 & $-0,5$ & $-1<\mathrm{km}<1$ & $\begin{array}{c}\text { Distribusi } \\
\text { Normal }\end{array}$ \\
\hline
\end{tabular}

Selain harus berdistribusi normal, data juga harus berasal dari populasi yang homogen. Oleh karena itu perlu dilakukan pengujian homogenitas. Pada penelitian ini, uji homogenitas data dilakukan uji $\mathrm{F}$ yaitu:

$$
F_{\text {hitung }}=\frac{\text { Varian terbesar }}{\text { Varian terkecil }} \quad \text { (Sudjana, }
$$
2005: 250)

$F_{\text {hitung }}=\frac{48,74}{29,38}$

$F_{\text {hitung }}=1,66$

Dari hasil perhitungan didapat $F_{\text {tabel }}=$ 1,74. Tampak bahwa $F_{\text {hitung }}<F_{\text {tabel. }}$. Hal ini 
berarti kedua data memiliki kesamaan varians atau kedua data bersifat homogen.

Adapun uji hipotesis yang normalitas dan homogenitas menggunakan uji t yang dapat dilihat pada tabel berikut:

Tabel 10.

Hasil Uji Hipotesis Tes Awal (Pretest)

\begin{tabular}{ccc}
\hline$t_{\text {hitung }}$ & $\begin{array}{c}\mathrm{T}_{\text {tabel }}(\text { taraf } \\
\text { kepercayaan } 5 \%)\end{array}$ & Keterangan \\
\hline 1,016 & 1,67 & $t_{\text {hitung }}<t_{\text {tabel }}$
\end{tabular}

Dari hasil interpolasi tersebut didapat harga $t_{\text {tabel }}=1,67$ sehingga $t_{\text {hitung }}=1,016$ $<t_{\text {tabel }}=1,67$ maka kesimpulannya adalah Ho diterima dan Ha ditolak. Sehingga dapat disimpulkan bahwa tidak ada pengaruh/ perbedaan yang signifikan antara kemampuan awal (Pretest) siswa kelas eksperimen dan kelas kontrol.

\section{3) Hasil Posttest}

Adapun hasil tes akhir/post-test siswa kelas eksperimen dan kelas kontrol dapat dilihat pada tabel dibawah ini:

Tabel 11.

\begin{tabular}{cccc}
\multicolumn{4}{c}{ Nilai Tes Akhir (Posttest) } \\
\hline Kelompok & $\begin{array}{c}\text { Nilai } \\
\text { tertinggi }\end{array}$ & $\begin{array}{c}\text { Nilai } \\
\text { rendah }\end{array}$ & Mean \\
\hline Eksperimen & 96 & 69 & 81,27 \\
\hline Kontrol & 88 & 48 & 68,78 \\
\hline
\end{tabular}

Uji normalitas data dilakukan dengan uji kemiringan kurva. Data dikatakan berdistribusi normal apabila harga kemiringan $-1<K m<1$. Hasil uji normalitas untuk masing - masing kelompok dan uji homogenitas pada tes akhir dilihat dalam tabel berikut ini:

Tabel 12.

Hasil Uji Normalitas Tes Akhir (Posttest)

\begin{tabular}{ccccc}
\hline Kelas & $\begin{array}{c}\text { Varian } \\
\mathrm{s}\end{array}$ & $\mathrm{Km}$ & Rentang & $\begin{array}{c}\text { Uji } \\
\text { Normalitas }\end{array}$ \\
\hline Eksperimen & 65,20 & 0,65 & $-1<\mathrm{km}<1$ & $\begin{array}{c}\text { Distribusi } \\
\text { Normal }\end{array}$
\end{tabular}

\begin{tabular}{cccc|} 
Kontrol & 110,5 & $-0,31$ & Distribusi \\
& 1 & Normal \\
\hline
\end{tabular}

Selain harus berdistribusi normal, data juga harus berasal dari populasi yang homogen. Oleh karena itu perlu dilakukan pengujian homogenitas. Pada penelitian ini, uji homogenitas data dilakukan uji $\mathrm{F}$ yaitu:

$$
F_{\text {hitung }}=\frac{\text { Varian terbesar }}{\text { Varian terkecil }}
$$

(Sudjana, 2005: 250)

$$
\begin{aligned}
& F_{\text {hitung }}=\frac{110,51}{65,20} \\
& F_{\text {hitung }}=1,69
\end{aligned}
$$

Dari hasil perhitungan didapat $F_{\text {tabel }}=$ 1,74. Tampak bahwa $F_{\text {hitung }}<F_{\text {tabel. }}$. Hal ini berarti kedua data memiliki kesamaan varians atau kedua data bersifat homogen.

Adapun uji hipotesis yang normalitas dan homogenitas menggunakan uji t yang dapat dilihat pada tabel berikut:

Tabel 13.

\begin{tabular}{ccc}
\multicolumn{3}{c}{ Hasil Uji Hipotesis Tes Akhir (Posttest) } \\
\hline$t_{\text {hitung }}$ & $\begin{array}{c}\mathrm{T}_{\text {tabel }}(\operatorname{taraf} \\
\text { kepercayaan } 5 \%)\end{array}$ & Keterangan \\
\hline 5,78 & 1,67 & $t_{\text {hitung }}>t_{\text {tabel }}$
\end{tabular}

Dari hasil interpolasi tersebut didapat harga $t_{\text {tabel }}=1,67$ sehingga $t_{\text {hitung }}=$ $5,78>t_{\text {tabel }}=1,67$ maka kesimpulannya adalah Ho ditolak artinya ada pengaruh pembelajaran dengan model pembelajaran Masterry Learning (belajar tuntas) terhadap kemampuan pemecahan masalah matematika siswa di SMA 'Aisyiyah.

4) Data N-Gain

Hasil N-gain siswa dapat dilihat pada tabel dibawah ini:

Tabel 14. 


\begin{tabular}{cccc}
\multicolumn{4}{c}{ Nilai N-gain } \\
\hline Kelompok & $\begin{array}{c}\text { Nilai } \\
\text { tertinggi }\end{array}$ & $\begin{array}{c}\text { Nilai } \\
\text { rendah }\end{array}$ & Mean \\
\hline Eksperimen & 0,94 & 0,65 & 0,77 \\
\hline Kontrol & 0,83 & 0,37 & 0,60 \\
\hline
\end{tabular}

Uji normalitas data dilakukan dengan uji kemiringan kurva. Data dikatakan berdistribusi normal apabila harga kemiringan $-1<K m<1$. Hasil uji normalitas untuk masing - masing kelompok dan uji homogenitas pada data $n$-gain dilihat dalam tabel berikut ini:

Tabel 15.

\begin{tabular}{|c|c|c|c|c|}
\hline Kelas & $\begin{array}{c}\text { Varian } \\
\mathrm{s} \\
\end{array}$ & $\mathrm{Km}$ & Rentang & $\begin{array}{c}\text { Uji } \\
\text { Normalitas }\end{array}$ \\
\hline Eksperimen & 0,01 & 0,7 & \multirow{2}{*}{$-1<k m<1$} & $\begin{array}{c}\text { Distribusi } \\
\text { Normal }\end{array}$ \\
\hline Kontrol & 0,013 & $-0,09$ & & $\begin{array}{c}\text { Distribusi } \\
\text { Normal }\end{array}$ \\
\hline
\end{tabular}

Selain harus berdistribusi normal, data juga harus berasal dari populasi yang homogen. Oleh karena itu perlu dilakukan pengujian homogenitas. Pada penelitian ini, uji homogenitas data dilakukan uji $\mathrm{F}$ yaitu:

$$
F_{\text {hitung }}=\frac{\text { Varian terbesar }}{\text { Varian terkecil }}
$$

(Sudjana, 2005: 250)

$$
\begin{aligned}
& F_{\text {hitung }}=\frac{0,013}{0,01} \\
& F_{\text {hitung }}=1,3
\end{aligned}
$$

Dari hasil perhitungan didapat $\mathrm{F}_{\text {tabel }}=$ 1,74. Tampak bahwa $F_{\text {hitung }}<F_{\text {tabel. }}$. Hal ini berarti kedua data memiliki kesamaan varians atau kedua data bersifat homogen.

Adapun uji hipotesis yang normalitas dan homogenitas menggunakan uji t yang dapat dilihat pada tabel berikut:

Tabel 16.

Hasil Uji Hipotesis N-gain

\begin{tabular}{ccc}
\hline$t_{\text {hitung }}$ & $\begin{array}{c}\mathrm{T}_{\text {tabel }}(\operatorname{taraf} \\
\text { kepercayaan } 5 \%)\end{array}$ & Keterangan \\
\hline 6,72 & 1,67 & $\mathrm{t}_{\text {hitung }}>\mathrm{t}_{\text {tabel }}$ \\
Maka & diperoleh & $t_{\text {hitung }}=6,72$ dengan
\end{tabular}

$\alpha=0,05, \mathrm{dk}=37+37-2=72$ tidak terdapat dalam tabel distribusi frekuensi, maka harus dicari dengan rumus interpolasi linier yaitu sebagai berikut:

$$
C=C_{o}+\frac{\left(C_{1}-C_{o}\right)}{\left(B_{1}-B_{o}\right)} .\left(B-B_{o}\right)
$$

(Riduwan,237: 2013)

Keterangan :

B : nilai db yang dicari

$B_{O}$ : nilai db pada awal nilai yang sudah ada

$B_{1}$ : nilai db pada akhir nilai yang sudah ada

$C$ : nilai $t_{\text {tebel }}$ yang dicari

$C_{o}$ : nilai $t_{\text {tebel }}$ pada awal nilai yang sudah ada

$C_{1}$ : nilai $t_{\text {tebel }}$ pada akhir nilai yang sudah ada

Dari hasil interpolasi tersebut didapat harga $t_{\text {tabel }}=1,67$ sehingga $t_{\text {hitung }}=$ $6,72>t_{\text {tabel }}=1,67$ maka kesimpulannya adalah Ho ditolak artinya ada pengaruh pembelajaran dengan model pembelajaran Masterry Learning (belajar tuntas) terhadap kemampuan pemecahan masalah matematika siswa di SMA 'Aisyiyah 1 Palembang.

\section{Pembahasan}

Penelitian eksperimen ini meneliti tentang ada atau tidaknya pengaruh perlakuan, dengan cara memberi perlakuan tertentu pada kelas eksperimen dan menyediakan kelas kontrol sebagai 
pembandingnya. Setelah menentukan kelas eksperimen dan kelas kontrol, peneliti memberikan perlakuan. Pada kelas eksperimen diberikan perlakuan berupa pembelajaran dengan menggunakan model pembelajaran mastery learning (belajar tuntas) dan pembelajaran pada kelas kontrol dilakukan secara konvensional dengan metode ceramah, tanya jawab dan pemberian tugas. Sebelum dilakukan perlakuan, pada pertemuan pertama masing-masing kelas baik eksperimen maupun kontrol diberikan tes awal (pretest) untuk mengetahui kemampuan awal siswa. Setelah diberikan perlakuan pada pertemuan kedua sampai pertemuan ketujuh, selanjutnya diberikan tes akhir (posttest) untuk mengetahui apakah ada pengaruh pada kemampuan pemecahan masalah matematika siswa yang telah diberikan perlakuan. Posttest pada kelas eksperimen dan kelas kontrol dilaksanakan pada pertemuan kedelapan.

Pada hasil penelitian menunjukkan adanya perbedaan perolehan nilai siswa pada kelas eksperimen dan kelas kontrol. Hal ini terlihat pada rekap nilai siswa dimana sebelum perlakua, kelas eksperimen memperoleh mean 22,26 dengan nilai tertinggi 31 dan nilai terendah 8 sedangkan kelas kontrol meannya 20,8 dengan nilai tertinggi 29 dan nilai terendah 6. Setelah perlakuan diperoleh mean posttest siswa kelas eksperimen 81,27 dengan nilai tertinggi 96 dan nilai terendah 69 sedangkan dari hasil posttest pada kelas kontrol diperoleh nilai tertinggi 88 dan terendah 48 dengan mean 68,78.
Dapat dilihat peningkatan melalui N-Gain siswa dikelas eksperimen mean 0,77 nilai tertinggi 0,94 dan nilai rendah 0,65 sedangkan kelas kontrol mean 0,60 nilai tertinggi 0,83 dan nilai terendah 0,37.

\section{Penutup}

Berdasarkan hasil penelitian dan pembahasan, maka dapat diambil kesimpulan sebagai berikut:

1. Berdasarkan data hasil penelitian diketahui bahwa rata-rata kemampuan pemecahan masalah matematika siswa dalam pembelajaran menggunakan model pembelajaran mastery learning (belajar tuntas) mengalami peningkatan yaitu 22,26 menjadi 81,27. Sedangkan nilai rata-rata $N$-gain kelas eksperimen adalah 0,77 dan rata-rata nilai $N$-gain kelas kontrol 0,60. Setelah dinormalitaskan dan homogenitaskan maka dapat dilakukan dengan pengujian hipotesis dan dari perhitungan uji $t$ diperoleh $t_{\text {hitung }}=6,72$ dan dengan $\alpha=0,05$ diperoleh $t_{\text {tabel }}=$ 1,67 yang berarti $t_{\text {hitung }}>t_{\text {tabel }}$ yaitu 6,72 $>$ 1,67. Hal ini menunjukkan bahwa $t_{\text {hitung }}>t_{\text {tabel, }}$ maka dapat dinyatakan bahwa Ho ditolak dan Ha diterima, yang artinya model pembelajaran mastery learning (belajar tuntas) berpengaruh terhadap kemampuan pemecahan masalah matematika siswa pada pelajaran matematika materi sistem persamaan linear.

2. Respon siswa dalam penelitian ini cukup baik. Siswa merasa senang dan aktif dalam mengikuti proses pembelajaran 
dengan model pembelajaran mastery learning (belajar tuntas) yang ditunjukkan dengan hasil rata-rata aktivitas kemampuan pemecahan masalah matematika siswa sebesar 74 .

Dengan memperhatikan hasil penelitian dan pembahasan, peneliti memberikan saran sebagai berikut:

1. Sebaiknya sebelum pelaksanaan pembelajaran menggunakan model pembelajaran mastery learning (belajar tuntas) guru harus menyiapkan soalsoal yang akan diberikan pada setiap tahapan yang ada.

2. Pada tahap pelaksanaan, sebaiknya guru menggunakan media atau alat peraga tambahan dalam menjelaskan materi. Pilihlah media atau alat peraga yang dapat mempersingkat waktu penjelasan tetapi tetap dapat dimengerti siswa.

3. Model pembelajaran mastery learning (belajar tuntas) membutuhkan waktu yang cukup banyak, sehingga guru harus mampu mengalokasikan waktu dengan baik agar pembelajaran dengan model pembelajaran mastery learning (belajar tuntas) dapat dilaksanakan dengan optimal.

4. Guru yang akan menggunakan model pembelajaran mastery learning (belajar tuntas) harus memahami secara mendalam unit pembelajaran yang akan disampaikan agar dapat menjawab semua pertanyaan siswa yang muncul.

5. Bagi penelitian selanjutnya, agar dapat menguji cobakan model pembelajaran mastery learning (belajar tuntas) tidak hanya menggunakan LKS saja tetapi disertai dengan media atau alat peraga agar siswa tidak merasa bosan dan bisa mengetahui manfaat nyata dari belajar matematika.

\section{Daftar PUstaka}

Majid, Abdul. Strategi Pembelajaran. 2013. Bandung: PT. Remaja Rosdakarya.

Riduwan. 2013. Dasar - dasar statistika. Bandung: Alfabeta

Sudijono, Anas. 2013. Pengantar Evaluasi Pendidikan. Jakarta: Rajawali Pers.

Sudjana. 2005. Metoda Statistika. Bandung: Tarsito.

Sugiyono. 2013. Metode Penelitian Pendidikan. Bandung: Alfabeta.

Sukardi, Ismail. 2013 Model-Model Pembelajaran Moderen. Palembang: Tuntas Gemilang Press.

Wena, Made. 2014. Strategi Pembelajaran Inovatif Kontemporer:Suatu Tinjauan Konseptual Operasional. Jakarta: Bumi Aksara. 